\title{
A Case of SIADH Induced by Mizoribin Administration
}

\author{
Yoko Fujino a Masaaki Inabaa Yasuo Imanishia Mayumi Nagata \\ Hitoshi Goto $^{a}$ Yasuro Kumeda ${ }^{a}$ Tatsuya Nakatani $^{\mathrm{b}}$ Eiji Ishimura $^{\mathrm{a}}$ \\ Yoshiki Nishizawa ${ }^{a}$
}

Departments of a M etabolism, Endocrinology and Molecular Medicine and bUrology, Osaka City University

Graduate School of Medicine, Osaka, J apan

\section{Key Words}

Syndrome of inappropriate secretion of antidiuretic hormone · Hyponatremia · Mizoribin · Drug •

Disease-modifying antirheumatic drugs

\begin{abstract}
We describe a 74-year-old man with rheumatoid arthritis (RA) who developed syndrome of inappropriate secretion of antidiuretic hormone (SIADH) 1.5 months after commencement of mizoribin prescription when his arthritis was improved. He noticed nausea and headache and serum $\mathrm{Na}$ fell as low as $118 \mathrm{mEq} / \mathrm{l}$. Normal urinary $\mathrm{Na}$ excretion without hypotension or hemoconcentration negated the possibility of dehydration resulting from urinary $\mathrm{Na}$ loss. Serum antidiuretic hormone (ADH) remained elevated at $0.59 \mathrm{pg} / \mathrm{ml}$ in spite of a significant reduction in serum osmolality to $254 \mathrm{mosm} / \mathrm{kg}$. He had no organic disease likely to cause SIADH. Despite infusion of hypertonic saline, his serum Na was not restored to normal. Shortly after mizoribin withdrawal, his serum $\mathrm{Na}$ increased significantly from 128 to $139 \mathrm{mEq} / \mathrm{l}$ and plasma osmolality from 265 to $287 \mathrm{mosm} / \mathrm{kg}$. ADH hypersecretion in relation to plasma osmolality was reversed by mizoribin withdrawal, suggesting that bredin-
\end{abstract}

in might adversely induce SIADH. Additional predisposing factors were the patient's age and difficulty in urination due to benign prostatic hypertrophy. In summary, we report herein the first case of SIADH believed to be an adverse effect of mizoribin, which may therefore needed to be added to the list of drugs which can induce SIADH.

Copyright $\odot 2002$ S. Karger AG, Basel

\section{Introduction}

A growing number of drugs cause syndrome of inappropriate secretion of antidiuretic hormone (SIADH) [1]. As the number of drugs used to treat rheumatoid arthritis (RA) has increased, these drugs, such as nonsteroidal antiinflammatory drugs (NSAIDs), disease-modifying antirheumatic drugs (DMARDs) and immunosuppressive drugs such as cyclophosphamide and methotrexate, have been increasingly reported to cause SIADH [2,3]. Mizoribin has recently been introduced as an immunosuppressive drug for RA [4].

We reported herein the first case of SIADH as a putative adverse effect of mizoribin and the condition disappeared shortly after cessation thereof.

\section{KARGER \\ Fax +4161306 1234 \\ E-Mail karger@karger.ch \\ www.karger.com

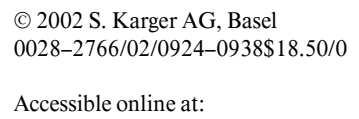

Masaaki Inaba, MD
Departments of Metabolism, Endocrinology and Molecular Medicine
Osaka City University Graduate School of Medicine
1-4-3, Asahi-machi, Abeno-ku 545-8585, Osaka (Japan)
Fax +81 66645 3806, Fax +81 66645 3808, E-Mail inaba-m@med.osaka-cu.ac.jp 


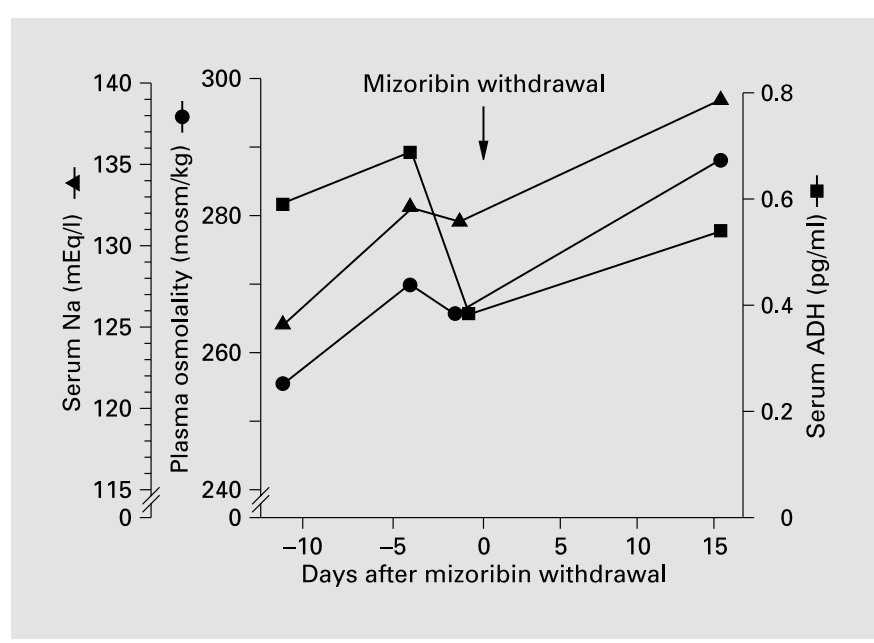

Fig. 1. Influence of mizoribin administration on serum $\mathrm{Na}$, serum $\mathrm{ADH}$, and plasma osmolality. During mizoribin administration, serum ADH remained exceedingly high in relation to his serum $\mathrm{Na}$ and plasma osmolality. However, mizoribin withdrawal significantly increased serum $\mathrm{Na}$ and plasma osmolality without increasing serum ADH. On day 15 after mizoribin withdrawal, serum ADH showed normal relationship to plasma osmolality and serum Na. Day 0 is the day when mizoribin administration was withdrawn.

\section{Case Report}

A 74-year-old man with RA was admitted to Osaka City University Hospital in 2000 . He had past history of benign prostatic hypertrophy (BPH) when an increase of serum creatinine to $1.5 \mathrm{mg} / \mathrm{dl}$ had first been noticed although its etiology was unknown. In 1984, he initially noticed swelling of bilateral wrists, and was subsequently diagnosed with RA. He has taken various NSAIDs including sulindac, diclofenac sodium and DMARD including auranofin, but without development of SIADH. His arthritis worsened in May 2000. Although salazosulfapyridine $(1,000 \mathrm{mg} /$ day $)$ was started in June 2000 , followed by mizoribin at $75 \mathrm{mg}$ daily 1 month later, his symptoms did not improve significantly. He was, therefore, admitted to our hospital on August 3 for further treatment. On the 12th hospital day, his symptoms had improved and CRP was decreased significantly from 4.4 to $2.2 \mathrm{mg} / \mathrm{dl}$. We assumed that the improvement of his RA activity was accounted for mainly by the effect of mizoribin because the improvement occurred 1.5 months after commencement of mizoribin prescription. On the 15th hospital day, nausea and headache appeared suddenly. Biochemical data indicated severe hyponatremia as his serum $\mathrm{Na}$ had decreased to $118 \mathrm{mEq} / \mathrm{l}$ with significant reduction in plasma osmolality $(254 \mathrm{mosm} / \mathrm{kg})$ (table 1). Considering his plasma osmolality, his serum ADH level of $0.59 \mathrm{pg} /$ $\mathrm{ml}$ was much higher than expected [5]. Na concentration in daily urine remained normal at $55 \mathrm{mEq} / \mathrm{l}$ with urine osmolality of $318 \mathrm{mosm} / \mathrm{kg}$. Hyponatremia resulting from either hemoconcentration due to $\mathrm{Na}$ loss or pseudohyponatremia was negated. The presence of organic disease including heart, liver, adrenal and thyroid gland, which might cause water retention, was also excluded by the normal clinical data. SIADH could not be explained by lung or brain dysfunction because of no mass on computed tomography. As the

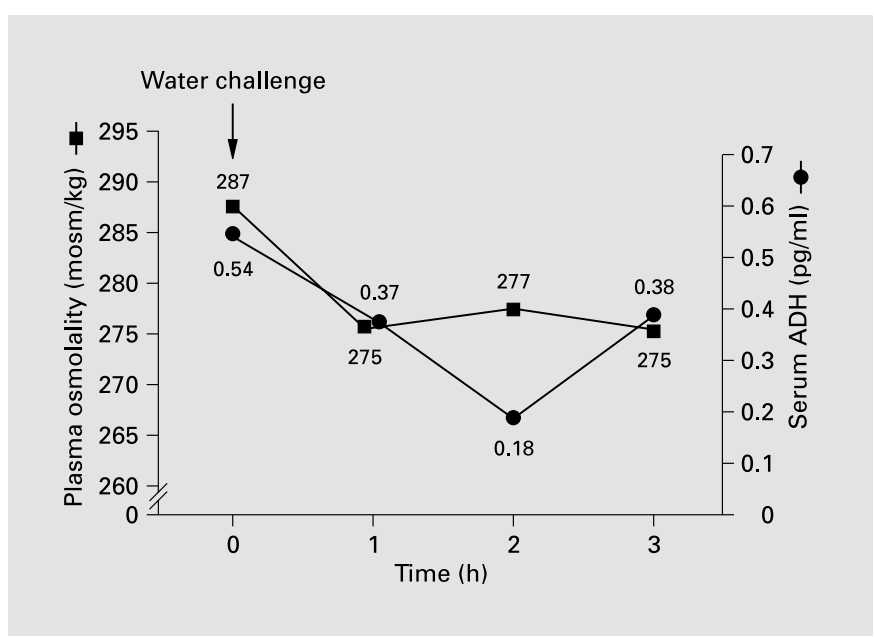

Fig. 2. Time-course changes in serum $\mathrm{ADH}$ and plasma osmolality during water challenge test. Water intake of $900 \mathrm{ml}$, i.e. $20 \mathrm{ml}$ water/ $\mathrm{kg}$ body weight, significantly suppressed serum ADH in a timedependent manner until $2 \mathrm{~h}$ after water load, with the lowest level of $0.18 \mathrm{pg} / \mathrm{ml}$ at $2 \mathrm{~h}$, and then increased it to $0.38 \mathrm{pg} / \mathrm{ml}$ at $3 \mathrm{~h}$, indicating that serum $\mathrm{ADH}$ had returned to normal regulation by plasma osmolality.
Table 1. Laboratory findings during hyponatremia

\begin{tabular}{ll}
\hline Blood urea nitrogen, $\mathrm{mg} / \mathrm{dl}$ & 20 \\
Serum creatinine, mg/dl & 1.47 \\
Serum Na, mEq/l & 118 \\
Serum K, mEq/l & 4.5 \\
Serum Cl, mEq/l & 83 \\
Plasma osmolality, mosm/kg & 254 \\
Urine osmolality, mosm/kg & 318 \\
ADH, ng/ml & 0.59 \\
Fasting plasma glucose, mg/dl & 101 \\
Free $\mathrm{T}_{3}, \mathrm{pg} / \mathrm{ml}$ & 1.7 \\
Free $\mathrm{T}_{4}, \mathrm{ng} / \mathrm{ml}$ & 1.3 \\
TSH, $\mu \mathrm{IU} / \mathrm{ml}$ & 1.043 \\
Serum cortisol, $\mu \mathrm{g} / \mathrm{dl}$ & 12.1 \\
24-hour urine free cortisol, $\mu \mathrm{g} / \mathrm{day}$ & 36 \\
ACTH, $\mathrm{pg} / \mathrm{ml}$ & 40.3 \\
Renin, $\mathrm{ng} / \mathrm{ml} / \mathrm{h}$ & 0.24 \\
Aldosterone, ng/ml & 7.5 \\
\end{tabular}

cause of drug-induced SIADH, since mizoribin was the most likely candidate as administration had started most recently, only about 1.5 months earlier, its administration was stopped on September 5 (fig. 1). Fifteen days later, serum $\mathrm{Na}$ was restored to the normal level of $139 \mathrm{mEq} / \mathrm{l}$. The serum ADH level of $0.54 \mathrm{pg} / \mathrm{ml}$ restored a normal relationship with the plasma osmolality of $287 \mathrm{mosm} / \mathrm{kg}$. In a water challenge test on September 20 (fig. 2), plasma osmolality decreased 
significantly from 287 to $275 \mathrm{mosm} / \mathrm{kg}$ in $1 \mathrm{~h}$ and then hovered around $277 \mathrm{mosm} / \mathrm{kg}$ until $3 \mathrm{~h}$ after sufficient water intake of $900 \mathrm{ml}$. Serum ADH decreased in a time-dependent manner until $2 \mathrm{~h}$ after water load with the lowest level of $0.18 \mathrm{pg} / \mathrm{ml}$ at $2 \mathrm{~h}$, and then increased to $0.38 \mathrm{pg} / \mathrm{ml}$ at $3 \mathrm{~h}$, confirming that serum $\mathrm{ADH}$ had returned to normal regulation by plasma osmolality.

\section{Discussion}

We report herein the first case of SIADH believed to be an adverse effect of mizoribin. This patient had no endocrine disease such as adrenal insufficiency or hypothyroidism to induce hyponatremia [6]. Furthermore, he had no renal, hepatic or cardiac disease to induce water retention. His urinary $\mathrm{Na}$ excretion and urine osmolality remained normal in spite of severe hyponatremia. Plasma contraction was also unlikely because of the absence of hypotension or increased serum creatinine or plasma hemoglobin. Additional risk factors for SIADH were the patient's age of 74 years and decreased urine production due to the difficulty in urination caused by BPH. The pos- sibility of tumor disease, which produces ADH autonomously, was also excluded. Evidence supportive of mizoribin-induced SIADH was the restoration of a normal relationship between serum ADH and plasma osmolality after mizoribin withdrawal, which was confirmed by the water challenge test (fig. 2). Of interest, it took as long as almost 1.5 months for mizoribin to cause SIADH simultaneously with efficacy against RA. Drugs used for the treatment of RA induce SIADH chemically within as little as 10 days after initial administration [1-3]. DMARDs often cause major adverse effects immunologically when the effect of the drug becomes evident. Although these observations may suggest that mizoribin may induce SIADH via the immune system, it is still possible that mizoribin causes ADH oversecretion directly, since serum $\mathrm{Na}$ restored to normal shortly after mizoribin withdrawal.

In summary, we described the first known case of SIADH believed to be an adverse effect of mizoribin in RA patients. Mizoribin may thus be necessary to be added to the list of drugs that can induce SIADH.

\section{References}

1 Kashyap AS, Kashyap S: Drug induced syndrome of inappropriate antidiuretic hormone secretion. Postgrad Med J 2000;76:319.

2 Petersson I, Nilsson G, Hansson BG, Hedner $\mathrm{T}$ : Water intoxication associated with non-steroidal anti-inflammatory drug therapy. Acta Med Scand 1987;221:221-223.
3 Bressler RB, Huston DP: Water intoxication following moderate-dose intravenous cyclophosphamide. Arch Intern Med 1985;145: 548-549.

4 Iwata H, Iwaki H, Masukawa T, Kasamatsu S, Okamoto H: Anti-arthritic activity of bredinin, an immunosuppressive agent. Experientia 1977;33:502-503.
5 Zerbe RL, Miller JZ, Robertson GL: The reproducibility and heritability of individual differences in osmoregulatory function in normal human subjects. J Lab Clin Med 1991;117:5159.

6 Okuno S, Inaba M, Nishizawa Y, Miki T, Inoue $\mathrm{Y}$, Morii $\mathrm{H}$ : A case of hyponatremia in panhypopituitarism caused by the primary empty sella syndrome. Endocrinol Jpn 1987; 34:299-307. 